\title{
A Literature Survey on UX Design Properties and Principles Of Smart Device Design for the Disabled: From the Perspective of the Value/Quality of Human Life
}

\author{
Joohwan Park ${ }^{1}$, Sung H. Han ${ }^{1}$, Mingyu Lee ${ }^{1}$, Hyeji Jang ${ }^{1}$ \\ ${ }^{1}$ Department of Industrial and Management Engineering, POSTECH, Pohang, Korea \\ shan@postech.ac.kr
}

\begin{abstract}
Nowadays, user experience (UX) is treated as an essential element to be considered by smart device designers. UX of the disabled is also considered important, as the welfare of the disabled has become a major issue in today's society. This study aims to propose a new concept of the value of UX, from the perspective of the human life value. UX design principles and UX design properties on a smart device design for the disabled were also defined to enhance the value of the smart device's experience. Literatures that related to UX, human/life value, and product/service's value were collected from various academic fields like philosophy, economics, ergonomics, and education to define and analyze the smart device UX. Industrial literatures related to smart device/application design guidelines, usability/accessibility guidelines were also collected to develop the UX design principles and properties. Collected literatures were analyzed to define the value elements of UX such as utilitarian value, affective value, and social value that affect the human life value of the disabled. UX design principles were developed based on the value elements of UX and existing design guidelines. The UX design properties were refined from the literatures.
\end{abstract}

Keywords: User Experience, Disability, UX Design, UX Design Principle, and UX Design Property

\section{Introduction}

User Experience (UX) is treated as an essential concern of product/service designers. As the welfare of the disabled has become a major issue in today's society, UX of the disabled has also become an important issue for designers. The Korean government has established several acts and decrees to encourage the disabled to participate in economic and social activities free from discrimination [13]. The Korean government has also established a policy that requires Assistive Technology (AT) to be provided to the disabled [4] to enhance the life quality and accessibility.

Smart devices, such as smart phones and tablets, are essential for modern life. As the smart device market has grown larger, manufacturers are forced to compete heavily for better UX, not only a better quality or function of the smart device. As a result, UX is treated as an essential element to be considered by smart device designers.

Smart devices are essential for the modern lives of the disabled, too. Smart devices with AT can provide accessibility to information and enhance the quality of life of the disabled. However, current smart device designers are only bound to accessibility or usability of user interface (UI), not UX. UX of the disabled is considered important, as their welfare is a major issue in the global society. As a result, UX design guidelines regarding smart devices for the disabled must be revised and enhanced from the UX perspective of the disabled. This study aims to establish the
UX design properties and principles to be considered by smart device designers for the disabled.

\section{Literature Survey}

A literature survey was performed to define UX design principles and properties. In total, 70 academic and industrial literatures were collected and analyzed. The literatures that contain, define, or analyze the concept of UX, human/life value, and product/service value were collected from various academic fields like philosophy, economics, ergonomics, HCI, sociology, and education. These literatures are used to define the value of UX and value elements.

Literatures containing UI/UX design guidelines were also collected from several organizations. Smart device/application design guidelines were collected from major smart device manufacturers, such as Apple, Microsoft, Google, and Samsung. Web and device accessibility guideline documents were also collected from several government/NGOs, such as WCAG and the Korean government. The collected literatures were used to define UX design properties and UX design principles.

\section{Literature Analysis}

Collected literatures were analyzed to define the value elements of UX. An analysis was performed in view of the 1) design properties influencing the UX that can be applied by the smart device designers and manufacturers, 2) values 
Table 1. UX Design Properties

\begin{tabular}{|c|c|c|c|c|}
\hline \multicolumn{2}{|c|}{ Category } & Description & UX Design Property & Examples \\
\hline \multirow{9}{*}{$\begin{array}{l}\text { Information } \\
\text { Design } \\
\text { Property }\end{array}$} & \multirow{4}{*}{$\begin{array}{l}\text { Information } \\
\text { Controls }\end{array}$} & \multirow{4}{*}{$\begin{array}{l}\text { - Forms, properties, and methods of } \\
\text { device inputs and controls to collect } \\
\text { information from the user }\end{array}$} & Text/Speech Input & $\begin{array}{l}\text { Verbal Command, Keyboard, Pen, Text Edit Menu } \\
\text { (Select, Copy, Paste, etc.) }\end{array}$ \\
\hline & & & $\begin{array}{l}\text { Image Drawing/Movie } \\
\text { Record }\end{array}$ & $\begin{array}{l}\text { Image Drawing, Photo Taking, Animation/Movie } \\
\text { Recording }\end{array}$ \\
\hline & & & Haptic Gesture & Touch Gesture, Motion Gesture, etc. \\
\hline & & & Other controls & $\begin{array}{l}\text { Non-verbal Sound Recognition, Physiological Signal, } \\
\text { Environmental Signal, etc. }\end{array}$ \\
\hline & \multirow{4}{*}{$\begin{array}{l}\text { Information } \\
\text { Perception }\end{array}$} & \multirow{4}{*}{$\begin{array}{l}\text { - Forms and properties of information } \\
\text { provided by the device to the user }\end{array}$} & Text Information & $\begin{array}{l}\text { Character (Font, Color, Typography, Size), Contrast, } \\
\text { Writing Style, etc. }\end{array}$ \\
\hline & & & Image/Icon/Animation/Movie & $\begin{array}{l}\text { Image, Icon, Color, Animation, Movie, Chart, Visual } \\
\text { Effect, etc. }\end{array}$ \\
\hline & & & Sound/Speech & $\begin{array}{l}\text { Verbal Speech (Pitch, Tone, Nuance, Diction, Grammar, } \\
\text { vocabulary), Nonverbal Sound, Alert, etc. }\end{array}$ \\
\hline & & & Haptic Feedback & Vibration, Force Feedback, etc. \\
\hline & $\begin{array}{l}\text { Information } \\
\text { Structure }\end{array}$ & $\begin{array}{l}\text { - Spatial and sequential } \\
\text { layout/structure of the information }\end{array}$ & $\begin{array}{l}\text { Navigation (Hierarchy) \& } \\
\text { Layout }\end{array}$ & $\begin{array}{l}\text { Menu structure, Menu sequence, View layout, Object } \\
\text { layout, Flow/sequence of the contents, etc. }\end{array}$ \\
\hline \multirow{8}{*}{$\begin{array}{l}\text { Hardware } \\
\text { Design } \\
\text { Property }\end{array}$} & \multirow{4}{*}{ Input Device } & \multirow{4}{*}{$\begin{array}{l}\text { - Physical modules/tools to input } \\
\text { information regarding their } \\
\text { properties }\end{array}$} & AT Input & $\begin{array}{l}\text { Special mouse for the disabled (Eyeball mouse, tongue } \\
\text { mouse, etc.), Braille keyboard, etc. }\end{array}$ \\
\hline & & & Motion Sensor & Accelerometer, etc. \\
\hline & & & Button, Keyboard & Button Size, Button Pressure, etc. \\
\hline & & & Touch Screen, Camera, MIC & Modules Size, Location, Performance, etc. \\
\hline & \multirow{2}{*}{$\begin{array}{l}\text { Output } \\
\text { Device }\end{array}$} & \multirow{2}{*}{$\begin{array}{l}\text { - Physical modules/tools to provide } \\
\text { information from the device to the } \\
\text { user }\end{array}$} & Display, Speaker & Modules Size, Location, Performance, etc. \\
\hline & & & AT Output & Braille display, etc. \\
\hline & \multirow{2}{*}{ Casing } & \multirow{2}{*}{$\begin{array}{l}\text { - Physical, external design of the } \\
\text { device }\end{array}$} & Texture \& Material & Case Texture, Glare, Temperature, Color, etc. \\
\hline & & & Volume \& Weight & Case Volume, Weight, Shape, etc. \\
\hline \multirow{3}{*}{$\begin{array}{l}\text { Functional } \\
\text { Design } \\
\text { Property }\end{array}$} & \multirow{2}{*}{$\begin{array}{l}\text { Provided } \\
\text { Feature } \\
\text { /Functions }\end{array}$} & \multirow{2}{*}{$\begin{array}{l}\text { - Properties of the contents of the } \\
\text { narrative/plots }\end{array}$} & Applications \& Functions & $\begin{array}{l}\text { Major/minor function that provided to user by the service } \\
\text { and product }\end{array}$ \\
\hline & & & $\begin{array}{l}\text { OS Level Assistive } \\
\text { Technology Features }\end{array}$ & $\begin{array}{l}\text { Features that implemented on the OS level to support the } \\
\text { usage of the product, service, and functions for the } \\
\text { disabled. }\end{array}$ \\
\hline & Narrative & $\begin{array}{l}\text { - Properties of the contents of the } \\
\text { narrative/plots }\end{array}$ & Plot \& Character & Plot, Character, Conflict, Events, Setting, etc. \\
\hline \multirow{2}{*}{$\begin{array}{l}\text { Sociability } \\
\text { Design } \\
\text { Property }\end{array}$} & $\begin{array}{l}\text { Brand \& } \\
\text { Marketing }\end{array}$ & $\begin{array}{l}\text { - Social, cultural, or religious image or } \\
\text { symbolic image of the } \\
\text { product/service/brand }\end{array}$ & Socio-Cultural Brand Image & $\begin{array}{l}\text { Socially/Culturally Shared Meanings, Brand Image, } \\
\text { Brand Value, Promotion and advertisement, etc. }\end{array}$ \\
\hline & After Service & $\begin{array}{l}\text { - Support system to solve the } \\
\text { problems that happen during use }\end{array}$ & Warranty \& Troubleshoot & $\begin{array}{l}\text { A/S Warranty, Quality Warranty, Technical support, } \\
\text { Internet support, etc. }\end{array}$ \\
\hline
\end{tabular}

provided by the smart device UX, and 3) design principles that must be considered to enhance the value of UX. Any keywords, concepts, and definitions were collected and analyzed to define the UX design properties and principles.

\subsection{UX Design Properties}

Tangible or intangible elements that can influence the satisfaction, value, and quality of UX of a smart device were collected from literatures. Major design properties collected from UI/UX accessibility guidelines were related to UI elements, hardware components, and AT modules/functions. Information design properties and hardware design properties were deduced and defined from the elements related to information processing and usability. On the other hand, several distinguishable elements were collected from philosophy, economics, sociology, and education fields. The narrative of the story, such as the properties of the main characters and plot or social discrimination by the brand or product type, is collected and considered an element influencing the UX. Functional design properties or social design properties were constructed with these intangible/abstract properties (See, Table 1.).

\subsection{Value of UX: UX Design Principles}

Literatures were also analyzed to understand the values provided by the smart device UX. Gutman [5] defined the products as potential satisfiers of people's value and Park and Han [6] defined the product/service value of the user as a subjective evaluation of a product/service that facilitates achieving the user's life value. As a result, the value of the smart device UX can be defined as the subjective evaluation of the experience that facilitates achieving the user's value. 
Table 2. Category of User Value Elements

\begin{tabular}{|l|l|l|}
\hline \multicolumn{1}{|c|}{ Value } & \multicolumn{1}{|c|}{ Definition } & \multicolumn{1}{c|}{ Examples } \\
\hline Utilitarian Value & Value achieved by fulfilling desires related to convenience/sloth & Convenience, Comfort, Relaxation, etc. \\
\hline Affective Value & Value achieved by fulfilling aesthetic/emotional desires & Appearance, Beauty, Cleanness, Sensitivity, Excitement, Cheer, etc. \\
\hline Social Value & Value achieved by fulfilling desires related to social/cultural activity & $\begin{array}{l}\text { Relationship, Friendship, Kinship, Love, Ethics, Belief, Self- } \\
\text { expression, Identity, Proud, Power, Ambition, Accomplishment, etc. }\end{array}$ \\
\hline Physiological value & $\begin{array}{l}\text { Value achieved by fulfilling desires related to survival, safety, and } \\
\text { reproduction }\end{array}$ & Security, Peace, Privacy, Breeding, etc. \\
\hline
\end{tabular}

Table 3. UX Design Principles

\begin{tabular}{|c|c|c|c|}
\hline Category & Description & $\begin{array}{l}\text { UX Design } \\
\text { Principle }\end{array}$ & Definition \\
\hline \multirow{10}{*}{$\begin{array}{l}\text { Utilitarian } \\
\text { Value } \\
\text { Principle }\end{array}$} & \multirow{10}{*}{$\begin{array}{l}\text { Design principles } \\
\text { to fulfill desires } \\
\text { related to } \\
\text { convenience and } \\
\text { sloth }\end{array}$} & Functional need & $\begin{array}{l}\text { Product/service's functions must be designed to meet user's varicose functional } \\
\text { requirements }\end{array}$ \\
\hline & & Flexibility & $\begin{array}{l}\text { Product/service must be designed to cope flexibly with the user's varicose usage contexts, } \\
\text { such as the task, environment, and user type }\end{array}$ \\
\hline & & Learnability & Product/service must be learned easily or memorized to use \\
\hline & & Efficiency & Product/service must be designed to achieve the purpose with the least effort \\
\hline & & Simplicity & Product/service must be designed to be simple \\
\hline & & Informativeness & Product/service must be designed to provide clear and detailed information \\
\hline & & $\begin{array}{l}\text { Error } \\
\text { Prevention }\end{array}$ & $\begin{array}{l}\text { Product/service must be designed to minimize user errors and to recover easily from the } \\
\text { errors }\end{array}$ \\
\hline & & Accessibility & Product/service must be designed to be accessible to information and control \\
\hline & & Consistency & Contents, structure, interaction, and design of product/service must be consistent \\
\hline & & Directness & Control of the product/service's function or interface must be given to users \\
\hline \multirow{7}{*}{$\begin{array}{l}\text { Affective } \\
\text { Value } \\
\text { Principle }\end{array}$} & \multirow{7}{*}{$\begin{array}{l}\text { Design principles } \\
\text { to fulfill } \\
\text { aesthetic/emotional } \\
\text { desires }\end{array}$} & Delicacy & Product/service must be designed to be delicate \\
\hline & & Reliability & Product/service must feel reliable \\
\hline & & Comfort & Product/service must feel comfortable and stable \\
\hline & & Simplicity & Product/service must feel clean, neat, and ordered \\
\hline & & Aesthetics & Product/service must feel aesthetically satisfactory \\
\hline & & Addictiveness & Product/service must be designed to make the user want to keep using the product/service \\
\hline & & Pleasure & $\begin{array}{l}\text { Product/service must be designed to make the user feel pleasure and delight when using the } \\
\text { product/service }\end{array}$ \\
\hline \multirow{5}{*}{$\begin{array}{l}\text { Sociability } \\
\text { Value } \\
\text { Principle }\end{array}$} & \multirow{5}{*}{$\begin{array}{l}\text { Design principles } \\
\text { to fulfill desires } \\
\text { related to } \\
\text { social/cultural } \\
\text { activity }\end{array}$} & Relationship & $\begin{array}{l}\text { Product/service must be designed to support the user to establish and maintain social } \\
\text { relationships }\end{array}$ \\
\hline & & $\begin{array}{l}\text { Socio-cultural } \\
\text { value }\end{array}$ & Product/service must be designed to meet the user's social/cultural/religious frameworks \\
\hline & & Pride & Product/service must be designed to make the user feel ascendant and superior to others \\
\hline & & Equality & Product/service must be designed to make the user not feel discriminated against by others \\
\hline & & Identity & Product/service must be designed to support the user to express their identity \\
\hline
\end{tabular}

To define a user's value, a total 61 value elements and their definitions were extracted and analyzed from 16 literatures. Duplicated or resembling elements were merged. Collected value elements were categorized into utilitarian value, affective value, social value, and physiological value. The proposed categories were based on the common categories used for the classifications of related academic works [7, 8, 9] (See, Table 2).

Physiological value refers to the most basic needs/desires of human beings that must be met [7]. However, based on this research, the physiological value is excluded, as the physiological needs are assumed to be already satisfied by the current smart device usage situation. Proposed value elements and categories were used to establish the UX design principles.

UX design principles collected from the literatures were re-arranged based on the value element categories. A number of usability principles collected from the UI/UX guidelines were designed to be major components of the utilitarian value principles. Affective value principles are based on the research of Part et al. [10] and several Kasei engineering literatures (See, Table 3 ). 


\section{Discussion and Conclusion}

This study aimed to collect and compile the UX design principles and properties of smart device design for the disabled from literatures. Several UX design properties and principles are drawn and categorized by the perspective of the human life value and the concept of the value of UX.

UX design principles and properties of smart device design for the disabled were also defined to enhance the value of the smart device's UX. Literatures related to UX, human/life value, and product/service value are collected from various academic fields, including philosophy, economics, ergonomics, and education, to define and analyze the elements of the smart device UX. Industrial literatures related to smart device/application design guidelines and usability/accessibility guidelines were also collected to develop the UX design principles and properties. Collected literatures were analyzed to define the value elements of UX, such as utilitarian value, affective value, and social value, which affect the human life value of the disabled. UX design principles were developed based on the value elements of the UX and existing design guidelines, and UX design elements were refined from the literatures.

This research has several limitations. Suggested design properties and principles must be verified and validated. Furthermore, systematical design methodologies are essential to apply the suggested concept to the smart device design process.

The results of this study could be used to help the disabled and smart device manufacturers evaluate the current state of UX of the disabled and enhance the designs of smart devices and related services. In conducting further research, the proposed UX design elements and UX design principles could be used to create a systematic methodology to generate detailed UX design guidelines for the disabled.

\section{Acknowledgement}

This research was supported by Basic Science Research Program through the National Research Foundation of Korea (NRF) funded by the Ministry of Education (No. 2013R1A1A2013231)

\section{References}

[1] Ministry of Health \& Welfare: Anti-Discrimination against and Remedies for Persons with Disabilities Act and Enforcement Decree, Republic Korea, 2011

[2] Ministry of Health \& Welfare: Act on Employment Promotion and Vocational Rehabilitation for Disabled Persons, Republic Korea, 1990

[3] Ministry of Health \& Welfare: Enforcement Decree of the Act on Employment Promotion and Vocational Rehabilitation for Disabled Persons, Republic Korea, 2011

[4] National Information Society Agency (한국정보화진흥원), Metropolitan City and Province (광역시도자치단체), Ministry of Security and Public Administration (행정안전부): A Public Work for
Distributing Information and Communication Assistive Devices (2012 정보통신 보조기기 보급사업 및 제품 안내), 2012

[5] Gutman J.: A means-end chain model based on consumer categorization processes, Journal of Marketing, 46(2):60-72, 1982

[6] Park J. and Han S. H.: Defining user value: A case study of a smartphone, International Journal of Industrial Ergonomics, 43(4):274-282, 2013

[7] Maslow A. H.: A theory of human motivation, Psychological review, 50(4):370, 1943

[8] Holbrook M. B.: Consumer value: A framework for analysis and research, Psychology Press, 1999.

[9] Boztepe S.: User Value: Competing Theories and Models, International journal of design, 1(2):55-63, 2007

[10] Park J., Han S. H., Kim H. K., Cho Y. and Park W.: Developing elements of user experience for mobile phones and services: Survey, interview, and observation approaches, Human Factors and Ergonomics in Manufacturing \& Service Industries, 23(3):279-293, 2013 